Insight, part of a Special Feature on Navigating Trade-Offs: Working for Conservation and Development Outcomes

\title{
Improving the Effectiveness of Interventions to Balance Conservation and Development: a Conceptual Framework
}

\author{
$\underline{\text { Stephen T. Garnett }}^{1}$, $\underline{\text { Jeffrey Sayer }}^{2}$, and $\underline{\text { Johan du Toit }}^{3}$
}

\begin{abstract}
There are numerous case studies around the world describing integrated conservation and development projects (ICDPs). Recently some localized syntheses have been published that use sophisticated statistics to identify patterns and causal linkages, but no attempt has yet been made to draw together lessons from across the globe. This paper is an attempt to provide a framework for such an analysis. A set of lessons is proposed for improving the prospects of ICDPs by giving consideration to each of the five capitals: natural, social, human, built, and financial. The language of ICDPs has been adopted by development agencies of all persuasions. There is now some urgency to identify the characteristics of the environment and the community in which success is most likely. This paper is intended as a step in that direction.
\end{abstract}

Key Words: integrated conservation and development, natural capital, social capital

\section{INTRODUCTION}

The first use of the term "integrated conservation and development project" (ICDP) that we have been able to locate was in the Luangwa Valley Integrated Conservation and Development Project jointly undertaken by FAO and the Government of Zambia in the mid-1960s (Child and Dalal-Clayton 2004). This project set out to manage wildlife sustainably for the benefit of the local people. Since then, the term ICDP has been widely applied to many different types of conservation initiatives. By the 1990s the concept had been embraced as a standard part of the aims of many major international organizations (Wells et al. 2004); organizations whose primary mission is conservation and those whose mission is development have both adopted the ICDP approach in some form (Campbell and Vainio-Mattila 2003). As a result, the definition of the ICDP has expanded, so that projects of this type are now described as "...approaches to the management and conservation of natural resources in areas of significant biodiversity value that aim to reconcile the biodiversity conservation and socioeconomic development interests of multiple stakeholders at local, regional, national and international levels" (Franks and Blomley 2004).
However, regardless of definition, there has been a long history of concern about the effectiveness of ICDPs in meeting either conservation or development objectives (Adams et al. 2004, McShane and Wells 2004). Integration is still the exception, and synergies do not emerge naturally (Barrett et al. 2005). Given the ubiquity of the rhetoric about reconciling the imperatives of local livelihood improvement with the desire to reduce, minimize, or even reverse environmental degradation, it might be assumed that an established methodology must be available to guide the implementation of these projects.

However, there is none. Analysis of many ICDPs has shown that success tends to be fleeting and fragile. Failure leads inevitably to loss of biodiversity, and purported successes are rarely associated with lasting improvements in the wealth and well-being of the communities in which the interventions were undertaken (McShane and Wells 2004, Robinson and Redford 2004, Sayer and Campbell 2004, Wells et al. 2004). Such successes are typically described in anecdotal case studies and often appear idiosyncratic, temporary, and contingent on local history, society, and environment. That said, there have been some 
longer-term success stories, and enough attempts at ICDPs that Sayer and Campbell (2004) believe it should be possible to construct hypotheses about the factors most likely to determine project outcomes that can be formally tested on a global scale. Ferraro and Pattanayak (2006) go a step further in suggesting that ICDPs need to be tested against a null hypothesis of no intervention at all, following medical models of evidence-based policy implementation (Sutherland et al. 2004).

A number of attempts have already been made to test hypotheses about the success and failure of ICDPs. Salafsky et al. (2002) tested the hypothesis that, if a viable enterprise is linked to the biodiversity of a protected area and generates benefits for a community of stakeholders, then the stakeholders will act to counter the threats to the resource (see also Salafsky et al. 2001). The results were inconclusive but suggested an alternative hypothesis: that conservation benefits from enterprise development around protected areas are products of the action learning that occurs during enterprise development itself, regardless of the enterprise's eventual financial success. More recently, Brooks et al. (2006) tested a set of hypotheses based on a numerical analysis of 28 selected ICDPs associated with protected areas drawn from a pool of 150 published papers. They postulated that success measured against a set of ecological, economic, attitudinal, and behavioral parameters would be improved through the extent to which protected areas are used by communities, the extent to which projects increase the integration of communities into wider markets, the degree of decentralization of decision making about conservation management, and the homogeneity of the communities associated with the protected areas. Their results suggested that decentralization was most likely to improve all four measures of success provided that strong local structures were in place. However, market integration and utilization had positive effects only on behavior and economics. Information on community homogeneity was rarely available, and no effects of this could be detected. The importance of decision-making decentralization is corroborated by Hayes and Ostrom (2005), who discovered, in a global review of forest conditions inside and outside reserves, that forest condition was related more closely to local involvement in setting rules on forest use than to any central system of park designation.
Agrawal and Chhatre (2006) took another approach. Following Agrawal (2001), they combined quantitative analysis with a qualitative approach using case studies to understand the biophysical, demographic, economic, institutional, and sociopolitical factors affecting the management of common property forests at 95 sites in the Indian Himalaya. Their results demonstrated the importance of biophysical constraints on outcomes and the likely biases in results if only the other factors are considered in the analysis. They also verified in a local setting theoretical assumptions about the link between local reliance on forest products and the condition of forests, about population stability compared to populations with a high rate of turnover, and about the importance of women. Their study, however, did not set out to measure the reverse relationship, i.e., the effect of environmental conditions on well-being, and only ambiguously considered the influence of interventions.

A local study of 40 community-based marine protected areas in the Philippines, which aimed to determine the frequency of win-win vs. lose-lose or trade-off outcomes as measured in terms of children's nutritional status and coral reef health, did look directly for such relationships but could conclude only that the enforcement of protection for marine protected areas did not have a negative effect on child health and may improve it over a longer period (Gjertsen 2005). Other studies, such as Gibson et al. (2005) and Struhsaker et al. (2005), used statistical techniques to examine specific issues such as the role of enforcement in natural resource quality. In the former, the quality of 191 forests scattered across most continents was correlated with the consistency of local enforcement; in the latter, the condition of 16 rainforest reserves in Africa correlated best with funding for enforcement and not at all with the presence of ICDPs.

Although these recent statistical approaches are usually based on conditions during a single short study period, the more common analyses of ICDPs have used case studies that cover the evolution of interventions over both longer and shorter periods of time. For instance, McShane and Newby (2004) described the findings from seven well-resourced Tropical Forest Portfolio projects run by the Dutch Directorate-General for International Cooperation and the World Wildlife Fund over 5 yr to test 
assumptions in the areas of livelihood development, capacity development, institutional support, and policy factors. For 13 assumptions, they found no fewer than 25 constraints inhibiting success, with the only consistent pattern being the need to work across a range of scales. They concluded that it was necessary to identify links between national and regional policy and local ICDP objectives, to recognize explicitly the trade-offs and compromises that were necessary, and to have donors who were willing to tolerate failure as part of a process of learning.

Drawing on a broader range of examples, Wells et al. (2004) identified a suite of factors that have been associated with failed ICDPs in the past, including over-optimistic goals, weak assumptions, unconvincing local participation, targeting of the wrong threats, uncertain financial sustainability, low benefit generation, and the need by donors for rapid success readily identifiable as their own. They go on to suggest that ICDPs are more likely to succeed when there is a proper understanding of the root causes of environmental degradation and when relevant national and regional policies are understood. It was also considered important that arrangements be in place for adaptive management, that targets and trade-offs be explicit, that the work be undertaken across a range of scales, that appropriate incentives for conservation be guaranteed, and that there be effective engagement with stakeholders.

A common criticism in recent analyses of ICDPs has been their failure to acknowledge the scarcity of win-win situations and the need to address tradeoff situations as part of integration (Robinson and Redford 2004). Adams et al. (2004) suggest that this shortcoming arises from the failure to recognize four realities of integrating conservation and development: (1) poverty and conservation are separate policy realms with little opportunity for integration, (2) conservation will be undermined unless poverty is alleviated, (3) there is a moral obligation for conservation not to compromise poverty reduction, and (4) poverty reduction itself depends on the conservation of living resources.

Additionally, in their review of the science of sustainable development, again based on case studies, Sayer and Campbell (2004) suggest that successful ICDPs require an understanding of existing environmental and social trajectories as well as action research and the use of both local and external knowledge. All significant stakeholders must be involved, and these stakeholders must also help determine appropriate measures of success. Sayer and Campbell (2004) also maintain that stable and fair tenure and governance arrangements and incentive payments are important and that natural resource scientists should be associated with management.

Many of these analyses have overlapping recommendations, and in this paper we take up the challenge of Sayer and Campbell (2004) to formulate a set of "lessons" on the factors likely to lead to successful ICDPs. Although these lessons are extracted from past and present experiments with ICDPs, we urge conservation and development analysts to formulate them as hypotheses for rigorous testing, drawing on the now numerous case studies around the world in ways that are statistically defensible.

\section{A CONCEPTUAL FRAMEWORK}

Integrated conservation and development projects (ICDPs) have taken widely varying approaches to addressing their objectives. Many of those sponsored by environmental organizations are staffed by biologists and focus on the management of the natural capital of the area. Humanitarian organizations often focus on the health, education, and skills of the human population, or the human capital. Government aid agencies have recently paid considerable attention to issues of legality, governance, law, and policy, i.e., social capital. Development banks are concerned with infrastructure and job creation, which are forms of built capital. Finally, many foundations have recently made attempts to achieve conservation through payments for environmental services, which enhances local financial capital.

When ICDPs aim to improve the capital assets of the area and its population, they invest in these five capital assets: natural, human, social, built, and financial (Carney 1998, Bebbington 1999). However, this type of investment often seems arbitrary because it fails to take into account local states and trends in capital assets that are already present. For instance, when people are living in extreme poverty, it will usually be more important to invest in their health and education and in the productivity of their agriculture than in the protection of their forests. When their material needs are adequately met, then the quality and 
sustainability of their lives may be better achieved by investing in their natural capital, for example, amenity and/or nature reserves.

Our central argument is that ICDPs have to be based upon an understanding of the states and trends of the capital assets of the concerned populations, and that interventions should be made in ways that lead to balanced and sustainable improvements in the capital assets framework (Campbell et al. 2001). This provides the foundation of a conceptual framework for designing conservation and development interventions. In the following sections we discuss the issues that have to be addressed when building the capital assets of an area in which there are both conservation and development needs.

\section{NATURAL CAPITAL}

\section{Biophysical context}

As noted by Agrawal and Chhatre (2006), remarkably few studies of integrated conservation and development projects (ICDPs) acknowledge biophysical constraints on the potential ways in which the two contrasting aims, conservation and development, can be reconciled, despite the fact that these studies are often undertaken by biologists. Soils, climate, and other biophysical factors place an absolute limit on the extent to which productivity can be enhanced to compensate for loss of production from the protected biodiverse parts of the landscape or to supply an increasing population. Many studies show that the extraction rates of nontimber forest products and other commodities that are potentially compatible with biodiversity conservation can rapidly exceed environmental limits. Nevertheless, there are also many naïve examples of attempts to increase the levels of extraction of such products without understanding the ecological constraints (e.g., Schröder 2001).

This does not mean that community development and conservation are impossible in landscapes operating near their physical capacity to support humans. Rather, as the ratio of humans to landscape productivity increases, the emphasis of external investment may need to shift from natural resource extraction to knowledge-based industries that do not remove resources from the immediate environment. However, knowledge-based industries are also under ecological constraints. Community-based ecotourism in particular is widely promoted as a key instrument of ICDPs, even though the empirical evidence for its effectiveness in either increasing wealth or protecting the environment is at best patchy (Wunder 2001, Salafsky et al. 2001, Kiss 2004a). For example, Burke (2004) and du Toit (2004) imply a negative correlation between per capita income from tourism and rainfall in Africa, because large animals are easier to see in open habitats, and the opportunity costs are lower, than in highly biodiverse and productive but visually impenetrable rain forest. Many of the most biodiverse sites are inaccessible and uncomfortable without major capital input and marketing that, in many cases, may threaten their conservation values. Although tourists are certainly malleable, business planning for community development must either budget for programs to change tourist preferences, siphoning money from other conservation initiatives (Kiss 2004a), or take existing preferences into account. Biophysical context is certainly a factor that needs to be considered in any analysis of outcomes from ICDPs based on tourism. It is also worth noting that most economic benefits from ecotourism accrue to exogenous investors and institutions rather than at the local level, and that pro-poor tourism has many differences from proconservation tourism (Ashley et al. 2000).

Wood carving (Campbell and Luckert 2002), other forms of art, transformed nontimber forest products, and bio-prospecting are also steps in the direction of a knowledge-based economy. Each implies an ongoing need to maintain the quality of the resource from which the products were obtained. All, however, are uncomfortably balanced between ecological constraints and economic reality. Increased production to meet development goals can threaten natural sustainable capacity and conservation goals, whereas higher prices for products increases the incentive for imitation and competition from external sources. Again, one of the ultimate constraints on ICDP success will be biophysical context.

The knowledge-based industry that would overcome these biophysical constraints would be the creation of a genuine market for biodiversity existence, either for its utilitarian values in terms of ecosystem services such as the capture of greenhouse gases and maintenance of water quality, or as an aesthetic end in itself. However neither market is yet established to the extent that it provides an alternative to industries that reduce biodiversity. 
The theoretical development of such a market, however, must take biophysical context into account in any valuation.

Lesson 1.1: ICDPs that match their ambitions to local biophysical productivity are more likely to succeed than those that consider only human, social, and economic factors.

\section{Landscape diversity}

Historically, many ICDPs concentrated only on areas of significant biodiversity, and often just on protected areas (Wells et al. 2004). Increasingly, these sites are being considered in a landscape context. This not only allows more diverse options for trade-offs but also makes it possible to maintain the activities and values within those landscapes in the face of change. The origins of the idea are Darwinian, with the implication that, the greater the variation in species, the greater their probability of adapting successfully to new selective processes. In biology, the benefits of herterozygosity and the disadvantages of inbreeding are well known. In ecology, there are parallels in intermediate levels of disturbance (Horn 1975, Connell 1978). In economics, there is financial risk hedging and portfolio diversification theory (Bernoulli 1954, Markowitz 1952, 1999). It follows that socialecological systems that include a diversity of ways in which people can interact with their environment for their social and economic benefit have a greater range of options in the event of shocks compared to those systems that lack variety, whether they be environmental or economic. This idea is encompassed by the concept of resilience, which is "...a measure of how far the system can be perturbed without shifting to a different regime" (Holling 1973, Walker et al. 2006).

A logical extension of such a hypothesis is that, for social-ecological systems to be resilient, they must contain redundancy, duplication, and a gradation in utility. Thus, maximizing short-term gain in a social-ecological system and minimizing redundancy reduces the capacity of the system to adapt to change. Just as rare species in ecological systems retain functional value at very low levels of abundance (Zavaleta 2004), so small fragments in a diverse landscape can play a vital role in that landscape's resilience and prosperity should conditions change. It also follows that unaltered landscapes, degraded landscapes, and those from which maximum gain is currently being extracted have inherently low levels of resilience, and that the further they are along any of those gradients, the greater the cost of restoring resilience (Holling 1973, Gunderson and Holling 2002). This does not mean that homogenous systems are not highly resistant to change. Rather, we would contend that, on appropriate temporal and spatial scales, when a homogenous system is perturbed, it is more likely than a heterogeneous system to shift to a different regime (e.g., Allison 2004).

Classifying natural systems with low levels of human influence as unstable in an analysis of resilience is counter-intuitive but follows from the assumption that a little-used system is more vulnerable to human pressure than one that has survived human-induced perturbation and for which humans acknowledge responsibility, even if that is simply a decision to enforce protection to prevent change. Finally, it also follows that, the further it is along a gradient, the greater the chances that the system will have crossed a resilience threshold from which no return to the original unaltered state is possible.

For ICDPs it therefore follows that the ones that invest across all forms of capital are likely to be more resilient than those that attempt to maximize investment in natural capital, even though that may be the prime motivation of the bodies facilitating the ICDP.

Lesson 1.2: Diverse landscapes are more resilient than uniform ones, and the greater the disparity between capital states, the greater the probability of rapid change in states.

\section{HUMAN CAPITAL}

\section{Demographic trends}

In many integrated conservation and development projects (ICDPs) and subsequent case study analyses, there appears to be an underlying assumption that the number of people in the landscape is relatively static. However, in resilience literature (Gunderson and Holling 2002), population change is one of the slow variables that can drive the dynamics of a system once a threshold has been passed. In setting up alternative enterprises to redirect demand from biodiverse parts of the landscape, there is rarely any discussion about what 
happens when those enterprises can no longer support a growing population, as though population growth is beyond the scope of ICDPs. This is partly a function of the "tyranny of projects" (Sayer and Wells 2004) that makes it difficult to take a longterm view. Nevertheless, in many cases, immediate threats to biodiversity are underpinned by the inexorable rise in population. Thus, the loss of fauna from Ghanaian parks as a result of bushmeat collecting is being accelerated by the reduction in the availability of fish protein caused by European fishing (Brashares et al. 2004), but this loss is probably inevitable in the face of the increase in the Ghanaian population and the lack of the economic development that would give Ghanaians the income levels needed to import protein.

Absolute population size can also affect the effectiveness of local regimes for governing natural resources. In pre-agricultural societies, humans usually interact closely with 150 other individuals but can readily recognize the faces of 2000 (Dunbar 1998), and it may be that, above this level, there is a threshold limit to the complexity of interactions that require a qualitatively different governance structure. Indonesian villages of more than 3000 inhabitants are thought to be too large to retain effective traditional management of marine resources (Harkes and Novaczek 2002), although this depends on such factors as access to wider markets (Cinner 2005), and villages with as many as 14,000 inhabitants were able to maintain effective traditional management in the 1990s (Evans et al. 1997). Trajectories in absolute population also have implications for market size (Sayer and Campbell 2004), which are then reflected in rates of resource exploitation. This can determine the nature and speed of the development needed to maintain existing standards of living, let alone improve them. Hence, absolute population size can be less important than the rate of change (Agrawal and Chhatre 2006), particularly in those areas in which the social capital that lubricates common property management breaks down, social memory and traditional knowledge are lost, and social responsibility for the environment is marginalized (Anderson 1991, Fentress and Wickham 1992, Riddett 1995, Rogoff 2000, Pretty 2003, Pretty and Smith 2004). Rapid immigration can disrupt the local management of natural resources even more than endogenous population growth (Cinner 2005), and sudden influxes of refugees or other migrants can sweep aside ICDPs based around local populations (O'Herron 2004), not least because of the time it takes to make new arrangements (Aswani and Hamilton 2004). However, where such changes have been considered at all it is usually in terms of community homogeneity, and even then such information is scarce (Brooks et al. 2006). Nevertheless, without information on demographic trends, including trends in health and education (Lutz and Goujon 2001), business planning for development returns and sustainable harvest rates is likely to be meaningless.

Lesson 2.1: ICDPs that consider, understand, and accommodate trends in human demography are more likely to demonstrate positive long-term trends in measures of success.

\section{Integrated conservation and development projects and community development}

Another limiting demographic factor in ICDP trajectories is the availability of appropriate skills. Delays in the importation or development of skills is a fundamental constraint on ICDPs (McShane and Newby 2004), whether they deal with natural resource management, governance, or business management. However, it is often not technical capacity in the direct management of ICDPs that is lacking. Rather, it is far more fundamental elements of societal capacity. Just as ICDPs are increasingly being conceptualized at a landscape scale, so it may be necessary to broaden the view of ICDPs and invest conservation funds more heavily in areas of traditional community development such as health, education, shelter, safety, and governance.

This places ICDPs firmly in the area of conventional development programs, with considerations of family planning, health, and education, especially for women, becoming pivotal. Literature on ICDPs suggests greater concern for the health of the environment than that of people, but the two are inextricably linked and need to be considered when hypotheses about ICDPs are tested. Although there is some concern that community development proposals have had to expand their focus to take the environment into account if they want to obtain funding (Campbell and Vainio-Mattila 2003) and that community development organizations sometimes ignore the social and financial benefits of wildlife conservation (Rogers 2005), those promoting ICDPs may need to broaden their focus if their conservation aims are to be sustained. 
Lesson 2.2: ICDP effectiveness is correlated with broad-based measures of human capacity development.

\section{SOCIAL CAPITAL}

\section{Democracy and integrated conservation and development projects}

As with other forms of community development (Campbell and Vainio-Mattila 2003), many integrated conservation and development projects (ICDPs) try to empower stakeholders by involving them in research and development at all stages so that they achieve ownership of the project objectives (Sayer and Campbell 2004). Frequently, this involves the empowerment of those with less power in the community, particularly women, who often have a vested interest in sustaining natural resources because they are usually the ones who collect and use them to maintain subsistence inputs to the household (Ostrom 1990, Agrawal and Chhatre 2006). Community development programs of this type are particularly effective at fostering "strong democracy," which is emerging as the major alternative to "thin democracy," national parliamentary representation that is often distant from community influence and generally promotes market-led globalization (Powell and Geoghegan 2006). There is empirical evidence that the democratization of decision making can benefit natural resource quality; in the Indian Himalaya, natural resource quality was more likely to be maintained in those areas in which there was a reasonable probability that community leadership could change (Agrawal and Chhatre 2006). Democratization can also reduce corruption, which is increasingly seen as a threat to conservation (Smith and Walpole 2005) and thus the effectiveness of ICDPs. On the other hand, strong, stable leadership can also have benefits. In Cameroon, the relative success of the conservation program at Kilum/Ijim is the result of the absolute authority of the local traditional leader, the Fon (Gartlan 2004), although such systems are rarely stable for long.

With respect to governance appraisal of ICDPs, progress may benefit from the application of the World Bank measures of the six dimensions of governance: (1) voice and accountability, (2) political stability and the absence of violence, (3) government effectiveness, (4) regulatory quality,
(5) the rule of law, and (6) control of corruption (Kaufmann et al. 2005). Such measures are regularly recorded at a national level, with the information on scores and trends freely available, and some can be applied at regional and local levels, although, to ensure that governance measures encompass local concerns, the six dimensions may be just the starting point for discussions about how to measure governance equity. Alternatively, there is a range of principles derived by Anderies et al. (2004) for robustness in social-ecological systems that have as their basis democratic principles and community involvement in decision making. Institutions that were fragile or collapsed had followed few of these principles; enduring ones had followed most of them.

Lesson 3.1: ICDP effectiveness is positively correlated with national and regional governance scores and/or indicators of robustness of socialecological systems.

\section{Tenure}

A lack of identified ownership of land or sea has long been seen as leading inevitably to the overexploitation of shared resources (Hardin 1968). Although there is ample theoretical and empirical evidence that cooperation is a fundamental element of human behavior based on sound theoretical principles (Hrushka and Heinrich 2006), and there are plenty of examples, at scales from local to global, to show that communities can develop rules for managing common property (Ostrom 1990), the lack of secure tenure is seen as particularly critical in those areas in which government has replaced traditional land ownership regimes (Adams 2001, Sayer and Campbell 2004). However, security of tenure is not always an effective means of protecting natural capital. When equitable tenure is established, it can then provide incentives to invest in built capital rather than conserve natural capital. Although sustainable management of natural resources is seen as one of the benefits of land reform, the capacity to invest in agricultural intensification is an even more desirable consequence (Feder and Nishio 1998, Deininger 2004). Nor does secure communal tenure necessarily protect natural values. Traditional marine tenure is secure under national law in New Guinea, but this has not prevented the overexploitation of coral (Cinner 2005), whereas, in Burkina Faso, traditional communal tenure is 
considered sufficiently secure to enable investment in agricultural intensification (Brasselle et al. 2002). At a more fundamental level, one result of the enclosure of the commons in 17th-century England was that those who used them felt no responsibility for them, a philosophy that suffuses modern capitalism and its concept of natural capital as a natural resource (Appleby 1976, 1978). Thus, secure tenure and land title may not be a universal panacea for poor management of the commons, and a hypothesis to test this should be developed.

Lesson 3.2: ICDPs are more effective in areas in which there are stable, transparent, and equitable systems of land or sea ownership.

\section{Sequencing interventions}

ICDPs would not be necessary if there were not a perceived need to change existing practices and disturb the established order. However, because power is relative, changes such as democratization inevitably reduce the power of others in society, either in government or in the community itself. Although the ICDP literature is effusive in its espousal of community empowerment, it is notably less forthcoming about techniques for decreasing the power of those who are already holding it, and usually there is strong resistance from vested interests (Adams 2001, McShane and Newby 2004, Child and Dalal-Clayton 2004, Agrawal and Chhatre 2006). In the Luangwa Valley in Zambia, transparent systems for distributing the benefits of integrated conservation and development exposed the corruption of senior chiefs, who were then deposed (Child and Dalal-Clayton 2004), but such examples are rare. The change in Zambia was possible only because the facilitators of the ICDP had worked in an appropriate sequence across several scales, strengthening local institutions while at the same time maintaining the resolve of the aid agency. This illustrates the interaction between the different scales of governance within which any ICDP will operate and the sequence in which interventions are undertaken.

The order in which interventions occur can be critical to eventual outcomes. For instance, if changes in land tenure laws are handled poorly, the results can include major conflicts (Deininger 2004), the development of landed elites (Adams 2001), or even the felling of forest to establish land ownership (Binswanger 1991). Nevertheless, in some countries there has been an orderly transfer of ownership from government to private or communal ownership with substantial benefits for the communities concerned (Deininger 2004). The key has been working at different levels of governance at the appropriate time. This applies to most ICDPs, which inevitably work within a multiscale environment with different complexities of governance at each level (Sayer and Campbell 2004).

Lesson 3.3: The effectiveness of ICDPs is improved by appropriately sequencing interventions across multiple scales and levels of governance.

\section{BUILT CAPITAL}

\section{The trade-off of built capital for natural capital}

Case studies of integrated conservation and development projects (ICDPs) rarely consider the importance of built capital to program persistence, and there is an underlying assumption that the creation of infrastructure generally increases the level of threat to natural capital values. The development component of ICDPs is thus commonly considered to be the development of social, financial, and human capital without the uncomfortable recognition that built capital may be a precondition for some of the other types of development. Sometimes the lack of built capital is an explicit measure of the value of natural capital, as in the definition of wilderness as being largely devoid of human influence, e.g., the U.S. Wilderness Act of 1963. This is in marked contrast to community development, in which the creation of housing or other facilities is a measure of success that reinforces social capital (Knotts 2006), because there is often a significant association between the development of built capital and subsequent increases in income (Fedderke et al. 2006). In poor societies, built capital may be the primary benefit derived from conservation projects (Hellquist 2004). In both literal and figurative senses, built capital is seen as a concrete measure of the success of development programs. In fact, built capital is sometimes the sole measure of success and, such is the durability of concrete, steel, and tar, that the construction of roads and solid buildings then shapes the society for which they were built (Scott 1998). 
The development of built capital almost always has both positive and negative effects on other capitals; some built capital can degrade other capitals even with the best intentions (e.g., Lam 1996). Certainly, goods usually need roads for transport to market; effective education is usually conducted under a roof; e-marketing needs computers, telecommunications, and sources of power; and tourists wealthy enough to improve local incomes usually demand physical comforts. However, each of these can involve tradeoffs. Roads for transformed, sustainably harvested nontimber forest products can carry logging trucks, education can provide no more than a passport to the city, and digital communication simply increases awareness of unattainable urban consumerism, whereas the byproduct of urban wealth, the rich fickle tourist, can destroy the very assets that attract them. Many of these assertions are common sense; some have been tested empirically, such as the negative association between access to markets and the strength of traditional governance regimes for marine resources (Cinner 2005). The results of this trend are also equivocal. Although Scott (1998) would maintain that the inexorable spread of built capital, while usually raising local health, education, and personal wealth, is essentially an extension of state control over its citizens, this allows greater exploitation or more effective protection of natural capital for all of the nation's citizens, not just those with immediate access to that capital. There are thus two inescapable questions: Is the development of built capital a necessary condition for the success of ICDPs, and under what circumstances has built capital contributed to positive trends in all capitals?

Lesson 4.1: It is necessary to trade off natural for built capital if other capitals are to increase and associated ICDPs are to persist.

\section{FINANCIAL CAPITAL}

\section{Environmental payments vs. belief systems}

One of the principal underlying assumptions of integrated conservation and development projects (ICDPs) is that there must be financial compensation for any loss of opportunity arising from biodiversity conservation. There is empirical evidence that biodiversity, as opposed to individual useful species and processes, is more valuable globally than locally (e.g., Kremen et al. 2000). As Kiss (2004b) maintains, those seeking biodiversity conservation in poor countries are usually external stakeholders competing with both local values and other external stakeholders who place greater value on the resources they can extract. In this sense, proponents of ICDPs follow a long tradition. The similarities between biodiversity advocates and religious missionaries in previous centuries are sometimes uncomfortably close (Grove 1989), and there are arguments that conservation biology has many of the characteristics of a religion (Taylor 2001). Alternatively, biodiversity conservation can be seen as a new form of colonialism, an incomprehensible imposed value that is only possible because of an economically driven power imbalance (Hellquist 2004), and it can be argued that payment for services makes this relationship explicit, transparent, and negotiable.

This approach, however, assumes that the motivations of all the communities requiring development are essentially materialistic. By implication, this suggests that the Stoic-Christian traditions, which deny any moral relationship between humans and nature (Passmore 1974), are universal, or at least that their universal domination is inevitable. In fact, materialistic attitudes to the environment only began to dominate in the west in the Middle Ages, as part of the efforts of the Catholic church to counter the "superstitions" of animism, and spread elsewhere round the globe through colonial mercantilism and Marxist analyses of capitalism (Appleby 1976, 1978, Thomas 1983). Outside the west, there are numerous long-standing unbroken traditions in the major religions (e.g., Sivaraksa 1989, Sharma et al. 1999, Khalid 2002, Negi 2005) and at the local level (e.g., Byers et al. 2001, Jones and Young 2004, Bhagwat et al. 2005, $\mathrm{Xu} 2005$ ) that effectively conserve biodiversity without financial compensation. In such cases, supporting those who advocate the maintenance of local traditions may be more effective than providing payments.

Other views are also long-standing in the Christian/ materialistic tradition. The modern concern with biodiversity and heavy investment in its protection are at least as much a consequence of 18th-century romanticism as of utilitarian arguments that biodiversity conservation is essential for the survival of the human species (Thomas 1983). The heterogeneity of environmental values may explain the equivocal results of analyses of ICDPs by Salafsky et al. (2002) and Brooks et al. (2006). Thus, there may be situations in which financial support 
may merely replace, and could undermine, local traditions of conservation.

Nevertheless, powerful economic forces and motivations usually do overwhelm both local philosophies that are consistent with conservation and those promulgated by proponents of ICDPs. Furthermore, religion can favor environmental degradation as much as oppose it (Greeley 1993). In many cases, regardless of philosophy, people living with nature cannot afford to bear the costs incurred by foregoing the opportunities offered by alternative and mutually exclusive land uses. For instance, as shown by the behaviour of the Punan in Kalimantan (Levang et al. 2003), few parents eschew opportunities to increase the probability that their children will survive, even if it means abandoning sustainable traditions. Further, community homogeneity is a myth. Even in traditional societies, at least some members of the community are actively seeking to increase their status through alternative exploitative land uses. The difficulty then is to provide sufficient ongoing funds to match alternatives, always being aware that any funding slippage may be irredeemable in terms of land-use change and biodiversity loss. The difficulty is that, beyond subsistence, poverty is relative, and the desire for status is never satisfied (de Botton 2004). Thus, it could be argued that financial compensation for those with food, water, security, and shelter is less effective in the long term than the internalization of the belief that biodiversity has intrinsic value by those making critical decisions about land use.

Lesson 5.1: Financial incentives are especially important in those areas in which belief-based constraints on environmental exploitation are ineffective.

\section{Contracts, targets, and milestones}

Assuming that payments of some kind are required for the provision of biodiversity services from communities that can either not afford to maintain them or do so only under duress, there remains the highly contentious issue of how best to pay for them. Ferraro (2001), Kiss (2004b), and others suggest that payments for environmental services (PES) are the most cost-effective means of improving the welfare of communities and of maintaining biodiversity, because they represent a simple trade based on measurable outputs, with payment being provided only on the basis of delivery (Wunder 2005). However, although this has been achieved effectively in places like Holland (e.g., Musters et al. 2001), Salafsky and Margoulis (2004), Wunder (2005), and others are sceptical about the practicalities in places in which institutions have less control, and can point to few examples in poor countries in which the idea has been taken up profitably and with enthusiasm.

In his recent review of PES, Wunder (2005) recognized four situations in which such payments are currently occurring: carbon sequestration, biodiversity protection, watershed protection, and landscape beauty. However, in each case there appeared to be a relatively narrow range of situations in which benefits were likely to accrue to local communities. A major concern is that a system of ongoing payments for ecosystem services means that those services persist only as long as there is a market for them. Any intermission in funding supply, a frequent problem when projects run for 5 yr or less, opens those services, and the resources on which they are based, to bids from other users. Alternatively, major inputs of conservation funding to set aside natural capital can disempower people by preventing them from undertaking what they see as legitimate land-development opportunities. The landless are likely to be the most disempowered, because they have no services to sell. In fact, PES can be counterproductive if, despite compensation, the loss of agricultural land leads to more hunting (Johannesen 2006).

Both cash or in-kind payments have drawbacks (Wunder 2005). An alternative strategy for delivering payments is through the employment of participants in action research with regular performance reviews, defining sustainability as an ongoing process of change and adaptation (Sayer and Campbell 2004). Payments are thus integrated into processes that provide other benefits to the community, as is reflected in the results of Salafsky et al. (2002). All these methods, however, are new, and their durability is still untested. Even case studies are relatively few, especially in poorer countries, and a lot of questions regarding the circumstances under which PES are most likely to be successful, how long they should last, how delivery should be enforced, and related costs all need to be answered before a testable hypothesis can be formulated. 
Lesson 5.2: Environmental payments are likely to be more effective in facilitating improved livelihoods if they are administered through contractual arrangements linked to targets and milestones.

\section{HYPOTHESIS TESTING}

There is some urgency to find patterns among integrated conservation and development projects (ICDPs) that work. Nearly all agencies wishing to undertake community development now use the language of sustainability and have aims that are ostensibly similar to those of ICDPs (Appendix 1). Although the extent to which different capitals are emphasized varies between organizations, the fundamental philosophies are the same. As Campbell and Vainio-Mattila (2003) pointed out, although integrated conservation and development have taken over the participatory community development agenda, neither the empirical nor the theoretical basis of success has been determined. It is certainly naïve to assume that any of these hypotheses can be tested independently. It is also likely that there will be a diverse range of correlates with successful and unsuccessful ICDPs, to say nothing of trying to perform the difficult task of testing what would have happened had no ICDP been attempted (Ferraro and Pattanayak 2006). Diversity in governance (Ostrom 2005) and in routes to sustainability (Kemp et al. 2005) is thought to be as important as genetic variation in the evolution of the robust social-ecological systems that are the ultimate objectives ICDPs.

To take the lessons we have proposed and test them as hypotheses will depend on the collection of enough relevant data at a range of appropriate temporal and spatial scales. Existing studies almost always acknowledge the limitations of small sample sizes, an excessive number of variables, and, often, the selective geographically or environmentally confined nature of their sample sizes (McShane and Newby 2004, Cinner 2005, Agrawal and Chhatre 2006). Similarly, Brooks et al. (2006) were unable to find adequate data to test a smaller range of hypotheses to their full extent.

There is, potentially, a far wider range of case studies from which to draw data than might be anticipated. As it is, some existing local data sets (e. g., Gjertsen 2005, Hayes and Ostrom 2005, Agrawal and Chhatre 2006) are impressively large and are already making it possible to test certain hypotheses. The adoption of sustainability principles by so many organizations with a wide variety of aims also expands the range of examples from which to draw data for analysis.

There is also an expanding range of statistical tools with which such data can be analyzed. A modern statistical portfolio includes influence diagrams, logic trees, Bayes nets, Monte Carlo simulations, fuzzy logic, and decision theory as well as multifactorial analysis, principal component analysis, and other more conventional techniques for data mining. An essential part of any model building will be the optimization of gain in all five capitals. Alternatively, one might test the social success of ICDPs using the new generation of happiness indices (e.g., Cummins et al. 2003); as recognised by Stem et al. (2005), ICDP monitoring and evaluation needs to learn a few lessons from the social sciences if it is to understand the processes leading to robustness and resilience. Ultimately, the aim of the analyses will be to identify the features of ICDPs that are most likely to achieve their diverse aims and give guidance where currently there are hunches and suppositions.

Responses to this article can be read online at:

http://www.ecologyandsociety.org/vol12/iss 1/art2/responses/

\section{Acknowledgments:}

Bruce Campbell was instrumental in bringing together the workshop where these ideas were discussed, and commented constructively on early drafts of the manuscript. Rene Boot and Sandeep Gupta contributed ideas to the discussions and Kristal Coe and Debbie Hall helped with references. Jeff Sayer acknowledges the support of the MacArthur Foundation to the project "Losing less and winning more: Building capacity to go beyond the trade-offs between conservation and development."

\section{LITERATURE CITED}

Adams, M. 2001. Tenure security, livelihoods and sustainable land use in Southern Africa. Pages 1-11 in Proceedings of the SARPN conference on Land Reform and Poverty Alleviation in Southern Africa 
(Pretoria, 2001). Southern African Regional Poverty and Development Network, Johannesburg, South Africa.

Adams, W. M., R. Aveling, D. Brockington, B. Dickson, J. Elliott, J. Mutton, D. Roe, B. Vira, and W. Wolmer. 2004. Biodiversity conservation and the eradication of poverty. Science 306:1146-1149.

Agrawal, A. 2001. Common property institutions and sustainable governance of resources. World Development 29:1649-1672.

Agrawal, A., and A. Chhatre. 2006. Explaining success on the commons: community forest governance in the Indian Himalaya. World Development 34:149-166.

Allison, G. 2004. The influence of species diversity and stress intensity on community resistance and resilience. Ecological Monographs 74:117-134.

Anderies, J. M., M. A. Janssen, and E. Ostrom. 2004. A framework to analyze the robustness of social-ecological systems from an institutional perspective. Ecology and Society 9(1):18. [online] URL: http://www.ecologyandsociety.org/vol9/iss1/ art18/.

Anderson, B. 1991. Imagined communities: reflections on the origins and spread of nationalism. Verso, London, UK.

Appleby, J. O. 1976. Locke, liberalism and the natural law of money. Past and Present 71:43-69.

Appleby, J. O. 1978. Economic thought and ideology in seventeenth-century England. Princeton University Press, Princeton, New Jersey, USA.

Ashley, C., C. Boyd, and H. Goodwin. 2000. Propoor tourism: putting poverty at the heart of the tourism agenda. Natural Resource Perspectives 51:1-6.

Aswani, S., and R. J. Hamilton. 2004. Integrating indigenous ecological knowledge and customary sea tenure with marine and social science for conservation of bumphead parrotfish (Bolbometopon muricatum) in the Roviana Lagoon, Solomon Islands. Environmental Conservation 31:69-83.

Barrett, C. B., D. R. Lee, and J. G. McPeak. 2005.
Institutional arrangements for rural poverty reduction and resource conservation. World Development 33:193-197.

Bebbington, A. 1999. Capitals and capabilities: a framework for analyzing peasant viability, rural livelihoods and poverty. World Development 27:2021-2044.

Bernoulli, D. 1954. Exposition of a new theory on the measurement of risk. Econometrica 22:23-36.

Bhagwat,S.A., C. G. Kushalappa, P.H. Williams, and N. D. Brown. 2005. A landscape approach to biodiversity conservation of sacred groves in the Western Ghats of India. Conservation Biology 19:1853-1862.

Binswanger, H. P. 1991. Brazilian policies that encourage deforestation in the Amazon. World Development 19:821-829.

Brashares, J. S., P. Arcese, M. K. Sam, P. B. Coppolillo, A. R. E. Sinclair, and A. Balmford 2004. Bushmeat hunting, wildlife declines and fish supply in west Africa. Science 306:1180-1183.

Brasselle, A. S., F. Gaspart, and J. P. Platteau. 2002. Land tenure security and investment incentives: puzzling evidence from Burkina Faso. Journal of Development Economics 67:313-418.

Brooks, J. S., M. A. Franzen, C. M. Holmes, M. N. Grote, and M. B. Mulder. 2006. Testing hypotheses for the success of different conservation strategies. Conservation Biology 20:1528-1538.

Burke, A. 2004. Conserving tropical biodiversity: the arid end of the spectrum. Trends in Ecology and Evolution 19:225-226.

Byers, B. A., R. N. Cunliffe, and A. T. Hudak. 2001. Linking the conservation of culture and nature: a case study of sacred forests in Zimbabwe. Human Ecology 29:187-218.

Campbell, B., J. A. Sayer, P. Frost, S. Vermeulen, M. Ruiz Pérez, A. Cunningham, and R. Prabhu. 2001. Assessing the performance of natural resource systems. Conservation Ecology 5(2): 22. [online] URL: http://www.consecol.org/vol5/iss2/art22/

Campbell, B. M. S., and M. K. Luckert. 2002. 
Uncovering the hidden harvest: valuation methods for woodland and forest resources. Earthscan, London, UK.

Campbell, L. M., and A. Vainio-Mattila. 2003. Participatory development and community-based conservation: opportunities missed for lessons learned? Human Ecology 31:417-436.

Carney, D. 1998. Sustainable rural livelihoods. What contribution can we make? Department for Internal Development, London, UK.

Child, B., and B. Dalal-Clayton. 2004. Transforming approaches to CBNRM: learning from the Luangwa experience in Zambia. Pages 256-289 in T. O. McShane and M. P. Wells, editors. Getting biodiversity projects to work: towards better conservation and development. Columbia University Press, New York, New York, USA.

Cinner, J. 2005. Socioeconomic factors influencing customary marine tenure in the Indo-Pacific. Ecology and Society 10(1): 36. [online] URL: http: //www.ecologyandsociety.org/vol10/iss1/art36/.

Connell, J. H. 1978. Diversity in tropical rain forests and coral reefs. Science 199:1302-1310.

Cummins, R. A., R. Eckersley, J. Pallant, J. van Vugt, and R. A. Misajon. 2003. Developing a national index of subjective wellbeing: the Australian Unity Wellbeing Index. Social Indicators Research 64:159-190.

de Botton, A. 2004. Status anxiety. Hamish Hamilton, London, UK.

Deininger, K. 2004. Land policies for growth and poverty reduction: key issues and challenges ahead. Pages 1-15 in UN, FIG, PC IDEA Inter-regional Special Forum on the Building of Land Information Policies in the Americas (Aguascalientes, 2004). Instituto Nacional de Estadística Geografía e Informática, Mexico City, Mexico.

du Toit, J. T. 2004. Response to Burke. Conserving tropical biodiversity: the arid end of the scale. Trends in Ecology and Evolution 19:226.

Dunbar, R. I. M. 1998. The social brain hypothesis. Evolutionary Anthropology: Issues, News, and Reviews 6:178-190.
Evans, S. M., M. E. Gill, A. S. W. Retraubun, J. Abrahamz, and J. Dangeubun. 1997. Traditional management practices and the conservation of the gastropod (Trochus nilitocus) and fish stocks in the Maluku Province (eastern Indonesia). Fisheries Research 31:83-91.

Fedderke, J. W., P. Perkins, and J. M. Luiz. 2006. Infrastructural investment in long-run economic growth: South Africa 1875-2001. World Development 34:1037-1059.

Feder, G., and A. Nishio. 1998. The benefits of land registration and titling: economic and social perspectives. Land Use Policy 15:25-43.

Fentress, J., and C. Wickham. 1992. Social memory: new perspectives on the past. Blackwell, Oxford, UK.

Ferraro, P. J. 2001. Global habitat protection: limitations of development interventions and a role for conservation performance payments. Conservation Biology 550:990-1000.

Ferraro, P. J., and S. K. Pattanayak. 2006. Money for nothing? A call for empirical evaluation of biodiversity conservation investments. PLoS Biology 4:e105.

Franks, P., and T. Blomley. 2004. Fitting ICD into a project framework: a CARE perspective. Pages 77-97 in T. O. McShane and M. P. Wells, editors. Getting biodiversity projects to work: towards better conservation and development. Columbia University Press, New York, New York, USA.

Gartlan, S. 2004. Land tenure and state property: a comparison of the Korup and Kilum ICDPs in Cameroun. Pages 208-231 in T. O. McShane and M. P. Wells, editors. Getting biodiversity projects to work: towards better conservation and development. Columbia University Press, New York, New York, USA.

Gibson, C., J. Williams, and E. Ostrom. 2005. Local enforcement and better forests. World Development 33:273-284.

Gjertsen, H. 2005. Can habitat protection lead to Improvements in human well-being? Evidence from marine protected areas in the Philippines. World Development 33:199-217. 
Greeley, A. 1993. Religion and attitudes toward the environment. Journal for the Scientific Study of Religion 32:19-28.

Grove, R. 1989. Scottish missionaries, evangelical discourses and the origins of conservation thinking in southern Africa 1820-1900. Journal of Southern African Studies 15:163-187.

Gunderson, L., and C.S. Holling. 2002. Panarchy: understanding transformations in human and natural systems. Island Press, Washington, D.C., USA.

Hardin, G. 1968. The tragedy of the commons. Science 162:1243-1248.

Harkes, I. H. T., and I. Novaczek. 2002. Presence, performance, and institutional resilience of sasi, a traditional management institution in Central Maluku, Indonesia. Ocean \& Coastal Management 45:237-260.

Hayes, T., and E. Ostrom. 2005. Conserving the world's forests: Are protected areas the only way? Indiana Law Review 38:595-617.

Hellquist, A. 2004. Are divergent preferences between benefactors and beneficiaries an obstacle to community-based conservation? A case study of the Palas Valley, northern Pakistan. Dissertation. Lund University, Lund, Sweden.

Holling, C. S. 1973. Resilience and stability of ecological systems. Annual Review of Ecology and Systematics 4:1-23.

Horn, H. S. 1975. Markovian properties of forest succession. Pages 196-211 in M. L. Cody and J. M. Diamond, editors. Ecology and evolution of communities. Belknap Press, Cambridge, Massachusetts, USA.

Hrushka, D. J., and H. J. Heinrich. 2006. Friendship, cliquishness and the emergence of cooperation. Journal of Theoretical Biology 239:1-15.

Johannesen, A. B. 2006. Designing integrated conservation and development projects (ICDPs): illegal hunting, wildlife conservation, and the welfare of the local people. Environment and Development Economics 11:247-267.
Jones, C. B., and J. Young. 2004. Hunting restraint by Creoles at the community baboon sanctuary, Belize: a preliminary survey. Journal of Applied Animal Welfare Science 7:127-141.

Kaufmann, D., A. Kraay, and M. Mastruzzi. 2005. Governance matters IV: governance indicators for 1996-2004. World Bank, Geneva, Switzerland.

Khalid, F. M. 2002. Islam and the environment. Pages 332-339 in P. Timmerman, editor. Social and economic dimensions of global environment change. John Wiley, Chichester, UK.

Kiss, A. 2004a. Is community-based ecotourism a good use of biodiversity conservation funds? Trends in Ecology and Evolution 19:232-237.

Kiss, A. 2004b. Making biodiversity conservation a land-use priority. Pages 98-123 in T. O. McShane and M. P. Wells, editors. Getting biodiversity projects to work: towards better conservation and development. Columbia University Press, New York, New York, USA.

Knotts, H. G. 2006. Sticks, bricks, and social capital: the challenge of community development corporations in the American deep south. Community Development Journal 41:37-49.

Kremen, C., J. O. Niles, M. G. Dalton, G. C. Daily, P. R. Ehrlich, J. P. Fay, D. Grewal, and R. P. Guillery. 2000. Economic incentives for rainforest conservation across scales. Science 288: 1828-1832.

Lam, W. F. 1996. Improving the performance of small-scale irrigation systems: the effects of technological investments and governance structure on irrigation performance in Nepal. World Development 24:1301-1315.

Levang, P., E. Dounias, and S. Sitorus. 2003. Out of the forest, out of poverty? Pages. 1-35 in Proceedings of the International Conference on Rural Livelihoods, Forests and Biodiversity (Bonn, 2003). Center for International Forestry Research, Jakarta, Indonesia.

Lutz, W., and A. Goujon. 2001. The world's changing human capital stock: multi-state population projections by educational attainment. Population and Development Review 27:323-339. 
Markowitz, H. M. 1952. Portfolio selection. Journal of Finance 7:77-91.

Markowitz, H. M. 1999. The early history of portfolio theory 1600-1960. Financial Analysts Journal 55:5-16.

McShane, T. O., and S.A. Newby. 2004. Expecting the unattainable: the assumptions behind ICDPs. Pages 49-76 in T. O. McShane and M. P. Wells, editors. Getting biodiversity projects to work: towards better conservation and development. Columbia University Press, New York, New York, USA.

McShane, T. O., and M. P. Wells. 2004. Integrated conservation and development? Pages 3-9 in T. O. McShane and M. P. Wells, editors. Getting biodiversity projects to work: towards better conservation and development. Columbia University Press, New York, New York, USA.

Musters, C. J. M., M. Kruk, H. J. de Graaf, and W. J. ter Keurs. 2001. Breeding birds as a farm product. Conservation Biology 15:363-369.

Negi, C. S. 2005. Religion and biodiversity conservation: not a mere analogy. International Journal of Biodiversity Science and Management 1:85-96.

O'Herron, M. 2004. Parks, projects, and policies: a review of three Costa Rican ICDPs. Pages 154-180 in T. O. McShane and M. P. Wells, editors. Getting biodiversity projects to work: towards better conservation and development. Columbia University Press, New York, New York, USA.

Ostrom, E. 1990. Governing the commons: the evolution of institutions for collective action. Cambridge University Press, Cambridge, UK.

Ostrom, E. 2005. Understanding institutional diversity. Princeton University Press, Princeton, New Jersey, USA.

Passmore, J. 1974. Man's responsibility for nature. Duckworth, London, UK.

Powell, F., and M. Geoghegan. 2006. Beyond political zoology: community development, civil society, and strong democracy. Community Development Journal 41:128-142.
Pretty, J. 2003. Social capital and the collective management of resources. Science 302:1912-1914.

Pretty, J., and D. Smith. 2004. Social capital in biodiversity conservation and management. Conservation Biology 18:631-638.

Riddett, L. 1995. Think again: communities which lose their memory: the construction of history in settler societies. Journal of Australian Studies 44:38-47.

Robinson, J. G., and K. H. Redford. 2004. Jack of all trades, master of none: inherent contradictions among ICD approaches. Pages 10-34 in T. O. McShane and M. P. Wells, editors. Getting biodiversity projects to work: towards better conservation and development. Columbia University Press, New York, New York, USA.

Rogers, P. J. 2005. Africa, Africanists, and wildlife conservation. African Studies Review 48:143-153.

Rogoff, I. 2000. Terra Infirma: geography's visual culture. Routledge, London, UK.

Salafsky, N., and R. Margoulis. 2004. Using adaptive management to improve ICDPs. Pages 372-396 in T. O. McShane and M. P. Wells, editors. Getting biodiversity projects to work: towards better conservation and development. Columbia University Press, New York, New York, USA.

Salafsky, N., G. Cauley, B. Balachander, J. Cordes, C. Parkes, C. Margoulis., S. Bhatt, C. Encarnacion, D. Russell, and R. Margoulis. 2001. A systematic test of an enterprise strategy for community-based biodiversity conservation. Conservation Biology 15:1585-1595.

Salafsky, N., R. Margoulis, K. H. Redford, and J. G. Robinson. 2002. Improving the practice of conservation: a conceptual framework and research agenda for conservation science. Conservation Biology 16:1469-1479.

Sayer, J., and B. Campbell. 2004. The science of sustainable development. Cambridge University Press, Cambridge, UK.

Sayer, J., and M. P. Wells. 2004. The pathology of projects. Pages 35-48 in T. O. McShane and M. P. Wells, editors. Getting biodiversity projects to work: towards better conservation and development. 
Columbia University Press, New York, New York, USA.

Schröder, J. -M. 2001. NTFP use and sustainability: the example of Prunus africana in Cameroon. ETFRN News 32:12-14.

Scott, J. C. 1998. Seeing like a state: how certain schemes to improve the human condition have failed. Yale University Press, New Haven, Connecticut, USA.

Sharma, S., H. C. Rikhari, and L. S. Palni. 1999. Conservation of natural resources through religion: a case study from central Himalaya. Society and Natural Resources 12:599-612.

Sivaraksa, S. 1989. Development and environment in south-east Asia. Zulak 24:429-436.

Smith, R. J., and M. J. Walpole. 2005. Should conservationists pay more attention to corruption? Oryx 39:251-256.

Stem, C., R. Margoulis, N. Salafsky, and M. Brown. 2005. Monitoring and evaluation in conservation: a review of trends and approaches. Conservation Biology 19:295-309.

Struhsaker, T. T., P. J. Struhsaker, and K. S. Siex. 2005. Conserving Africa's rain forests: problems in protected areas and possible solutions. Biological Conservation 123:45-54.

Sutherland, W.J.,A.S. Pullin, P. M. Dolman, and T. M. Knight. 2004. The need for evidence-based conservation. Trends in Ecology and Evolution 19:305-308

Taylor, B. 2001. Earth and nature-based spirituality (part I): from deep ecology to radical environmentalism. Religion 31:175-193.

Thomas, K. 1983. Man and the natural world. Allen Lane, London, UK.

Walker, B. H., J. M. Anderies, A. P. Kinzig, and P. Ryan. 2006. Exploring resilience in socialecological systems through comparative studies and theory development: introduction to the special issue. Ecology and Society 11(1): 12. [online] URL: http://www.ecologyandsociety.org/vol11/iss1/art12/
Wells, M. P., T. O. McShane, H. T. Dublin, S. O'Connor, and K. H. Redford. 2004. The future of integrated conservation projects: building on what works. Pages 397-422 in T. O. McShane and M. P. Wells, editors. Getting biodiversity projects to work: towards better conservation and development. Columbia University Press, New York, New York, USA.

Wunder, S. 2001. The economics of deforestation: the example of Ecuador. Palgrave Macmillan, Basingstoke, UK.

Wunder, S. 2005. Payments for environmental services: some nuts and bolts. CIFOR, Bogor, Indonesia.

Xu, J., E. T. Ma, D. Tashi, Y. Fu, Z. Lu, and D. Melick. 2005. Integrating sacred knowledge for conservation: cultures and landscapes in southwest China. Ecology and Society 10: 7. [online] URL:

http://www.ecologyandsociety.org/vol10/iss2/art7/

Zavaleta, E. S., and K. B. Hulvey. 2004. Realistic species losses disproportionately reduce grassland resistance to biological invaders. Science 306:1175-1177. 


\section{APPENDIX 1}

Table A-1. Objectives of a selection of international conservation and development agencies showing the extent to which the rhetoric of integrated conservation development has been adopted.

\begin{tabular}{lll}
\hline \hline Emphasis & Name & Mission \\
\hline Conservation & $\begin{array}{l}\text { Convention on International Trade in } \\
\text { Endangered Species of Wild Fauna and } \\
\text { Flora (CITES) }\end{array}$ & $\begin{array}{l}\text { To ensure that international trade in specimens of wild animals } \\
\text { and plants does not threaten their survival }\end{array}$
\end{tabular}

Nature Conservancy

Flora and Fauna International

A balance Conservation International between conser-

vation and development
To preserve the plants, animals, and natural communities that represent the diversity of life on Earth by protecting the lands and waters they need to survive

To protect the entire spectrum of endangered plant and animal species on the planet

To conserve the Earth's living natural heritage and global biodiversity, and to demonstrate that human societies are able to live harmoniously with nature

To achieve agreed-upon global environmental benefits in areas such as biological diversity; climate change; international waters; land degradation, primarily desertification and deforestation; ozone layer depletion; and persistent organic pollutants

To influence, encourage, and assist societies throughout the world to conserve the integrity and diversity of nature and to ensure that any use of natural resources is equitable and ecologically sustainable

Wildlife Conservation Society

To save wildlife and wild lands, change attitudes toward nature, and help people imagine wildlife and humans living in sustainable interaction on both a local and a global scale

To protect biological diversity and ensure that future generations can live on a planet with a wider diversity of species and habitats as well as clean air and water, healthy soil, and as many nonrenewable resources as possible

To create a peaceful and sustainable world based on societies living in harmony with nature and ensure social, economic, gender, and environmental justice free from all forms of domination and exploitation
Friends of the Earth International (FOEI) 
BirdLife International

World Wide Fund for Nature (WWF)

WorldFish Centre

World Agroforestry Center

International Plant Genetic Resources Institute (IGPRI)

Norwegian Agency for Development Cooperation (NORAD)

International Water Management Institute (IWMI)

International Centre for Underutilised Crops (ICUC)

Center for International Cooperation in Agricultural Research for Development (CIRAD)

Tropenbos

Center for International Forestry Research (CIFOR)

International Rice Research Institute (IRRI)
To help, through birds, to conserve biodiversity andimprove the quality of people's lives; to integrate bird conservation into sustaining people's livelihoods

To stop the degradation of the planet's natural environment and build a future in which humans live in harmony with nature

To enhance the well-being of present and future generations of poor people in the developing world through improved production, management, and conservation of living aquatic resources

To work toward mitigating tropical deforestation, land depletion, and rural poverty through improved agroforestry systems

To advance the conservation and use of genetic diversity for the well-being of present and future generations

To combat poverty and contribute to lasting improvements in living standards and quality of life; to promote peace, democracy, and human rights and the responsible management and use of the global environment and biological diversity

To improve water and land resources management for food livelihoods and nature

To reduce poverty and suffering through the improvement and promotion of underutilized crops for food, medicines, fodder, and industrial needs, and also for environmental protection

To contribute to rural development in tropical and subtropical countries in the fields of agriculture, forestry, and agrifoods, including environmental issues and natural resource management

To improve forest management for the benefit of people, conservation, and sustainable development

To conserve forests and improve the livelihoods of people in the tropics; to help local communities and small farmers gain their rightful share of forest resources while increasing the production and value of forest products

To improve the well-being of present and future generations of rice farmers and consumers, particularly those with low incomes; to generate and disseminate rice-related knowledge and technology of short- and long-term environmental, social, and economic benefit 
International Institute of Tropical Agriculture (IITA)

International Food Policy Research Institute (IFPRI)

Centro Internacional de Agricultura Tropical (CIAT)

Africa Rice Center (WARDA)

Australian Centre for International Agricultural Research (ACIAR)

Centro Internacional de Mejoramiento de Maiz y Trigo (CIMMYT)

International Center for Agricultural Research in the Dry Areas (ICARDA)

Centro Internacional de la Papa (CIP)

International Crops Research Institute for the Semi-Arid Tropics (ICRISAT)

Consultative Group for International Agricultural Research (CGIAR)

Economic deve- International Development Research lopment

Centre (IDRC)
To enhance the food security, income, and well-being of resource-poor people in sub-Saharan Africa; to increase agricultural production, improve food systems, and sustainably manage natural resources

To improve food security and nutrition, with an emphasis on low-income countries and poor people and on the sound management of the natural resources base that supports agriculture

To conduct socially and environmentally progressive research aimed at reducing hunger and poverty and preserving natural resources in developing countries

To contribute to poverty alleviation and food security and to increase the productivity and profitability of the rice sector in ways that ensure the sustainability of the farming environment

To improve sustainable agricultural production in developing countries

To serve the poor in developing countries; to increase food security, improve the productivity and profitability of farming systems, and sustain natural resources

To improve the welfare of poor people and alleviate poverty through research and training in dry areas of the developing world, by increasing the production, productivity, and nutritional quality of food while preserving and enhancing the natural resource base

To reduce poverty and achieve food security on a sustained basis in developing countries by improved management of natural resources in the Andes and other mountain areas

To serve the poorest of the poor in the semi-arid areas of the developing world and to give a human face to the science and agricultural research that we do with our partners

To achieve sustainable food security and reduce poverty in developing countries in the fields of agriculture, livestock, forestry, policy, and natural resources management

To solve critical development problems 
Australian Agency for International Development (AusAID)

International Livestock Research Institute (ILRI)

Technical Centre for Agricultural and Rural Cooperation (CTA)

UK Department of International Development

International Fund for Agricultural Development (IFAD)

International Development Association (IDA)

United States Agency for International Development (USAID)
To advance Australia's national interest by helping developing countries reduce poverty and achieve sustainable development

To improve agricultural systems in which livestock are important

To develop and provide services that improve access to information for agricultural and rural development

To combat the spread of HIV and AIDS in Africa, promote poverty reduction programs, reduce debt, boost access to markets, and support peace processes

To enable the rural poor to overcome poverty

To promote economic development, increase productivity, and thus raise standards of living in the less-developed areas of the world

To encourage long-term and equitable economic growth and advance U.S. foreign policy objectives by supporting economic growth, agriculture, and trade; global health; and democracy, conflict prevention, and humanitarian assistance 